\title{
Review
}

\section{Staged: Show trials, political theater, and the aesthetics of judgment}

\author{
Minou Arjomand \\ New York, Columbia University Press, 2018, 248 pp., \\ ISBN: 9780231184885
}

Contemporary Political Theory (2020) 19, S134-S137. https://doi.org/10.1057/s41296019-00308-0; published online 23 January 2019

This book sets itself an ambitious and timely goal: to examine the multiple interfaces between law and theatre. Both in the court room and on stage, judgments are issued and solicited, demanded and contested: how do these types of judgment stand in relation to each other? Do they share specific characteristics, or should we rather treat them as different in kind - the former aiming for legally binding objectivity, while the latter strive for agreement through deliberation or acclamation?

These questions are as pressing today as they have ever been, for at least two interrelated reasons: trials resemble, in obvious and sometimes less obvious ways, theatre performances, and we want to better understand what forms of theatricality are intrinsic to court proceedings and what forms should be deemed problematic. Secondly, when spectators watch a play on stage, their ability to judge might also inform the civic activity of evaluating what is going on in the wider public, once the performance is over. In other words, Arjomand's interest in the interface between law and theatre is both politically and aesthetically motivated. This double interest underpins the book's originality.

Arjomand reconstructs the complex relations between law and theatre within a particular context: German theatre from roughly 1918 to 1968 . The book is divided into five parts, three centred around crucial historical figures - Hannah Arendt, Bertolt Brecht and Erwin Piscator - one chapter dedicated to a documentary theatre play (Trial in Nuremberg) and a conclusion that deals with law and theatre today. This peculiar structure throws up some problems, but before I turn to my interpretation, a summary of the main argument is in order. Given the book's erudition and scope, I shall merely focus on some of the central motifs running through it.

The chapter on Arendt initially treads relatively familiar territory, focusing especially on Eichmann in Jerusalem. Arjomand convincingly demonstrates that Arendt's main concern about the Eichmann trial was not so much its theatrical

(C) 2019 Springer Nature Limited. 1470-8914 Contemporary Political Theory Vol. 19, S2, S134-S137 
nature (the performance of both defendant, prosecutors, judges and witnesses) per se, but rather that it was mistakenly modelled on a tragic understanding of the Holocaust and of Eichmann himself, whose sentencing was supposed to trigger to a collective cathartic experience. If tragedy provided the wrong theatrical genre for framing the judgment on Eichmann's acts, which one would have been better suited? At this stage, Arjomand introduces the reader to one of several points of contact between Arendt and Brecht, proposing that 'each of them responded to Fascism by linking philosophy with theatre' (p. 27).

In Arendt's case, the chief purpose of theatre lay in its capacity to reveal, in a controlled environment, a certain form of action that she considered central to politics in general: when actors perform on stage, they will earn applause especially when they exceed and transform habitual roles; virtuosity is pivotal to her account of stagecraft. This point is important because it opens up a way for thinking about politics as oriented through exemplary action. Arjomand's argument here is that Arendt's view of theatre as a political institution is so powerful because it remains thoroughly anti-didactic: 'Theatre is essential not because it is a moral institution that teaches law but because it is a space where people judge in the company of others without recourse to a universal law' (p. 53).

The chapter on Brecht might be of even more interest to political theorists than the one on Arendt. Arjomand shows that Brecht's conception of epic theatre is closely bound up with his understanding of real-world trials. Of special relevance here appear to be the Moscow Trials, held between 1936 and 1938, whereby Stalin sought to purge political opponents within the Soviet apparatus. Brecht's objection to the proceedings is curious: precisely because the trials were set up in a highly realistic manner, with the 'defendants' freely confessing to the crimes they were accused of, they seemed fraudulent to Brecht.

This critical stance can be further explained by Brecht's theory and practice of theatre-making. Epic theatre crucially requires the actor to maintain distance to the role that she is playing. Only through the use of estrangement devices will the audience be enabled to judge what is happening on stage and draw adequate lessons for their own dilemmas. Brecht applied this account of epic theatre not only to appraising the Moscow Trials, but also deployed it in his own defence. When, after his escape to the USA, Brecht was himself dragged before the House Un-American Committee for suspected involvement in the Communist cause, he used a defence strategy that was effectively based on his theory of acting: 'Brecht took the opposite tack from the one Bukharin had taken in Moscow. While Bukharin confessed to a "duality of mind" as a weakness, Brecht defended himself by giving an account of both his own politics and his work that was too fragmented for the committee to grasp' (p. 66).

If both Arendt and Brecht are well-known stalwarts of the Western canon of political thought, Arjomand's third figure appears to be a more eccentric choice. Erwin Piscator, a German playwright and director with remarkable political

(C) 2019 Springer Nature Limited. 1470-8914 Contemporary Political Theory Vol. 19, S2, S134-S137 S135 
foresight, developed an account of epic theatre that stands in significant contrast to Brecht's. While Brecht positioned his conception of theatre against the Aristotelian tradition of drama, with its emphasis on identification and catharsis, Piscator attempted to drive theatre in a different direction, by 'first, providing historical depth through the introduction of documentary material and, second incorporating the audience in the action' (p. 98). In contrast to Brecht's rejection of the stage as a realistic depiction of the truth, Piscator emphatically embraced 'documentary theatre' and its aim of shocking the viewers by abolishing the divide between stage and audience. Arjomand's discussion of Piscator's approach to epic theatre is both detailed and fascinating, especially in her excellent analysis of the politics of casting.

In his production of Peter Weiss's play The Investigation, which rehearses the Frankfurt Auschwitz trials, Piscator insisted on casting only Jewish actors to play the survivors - a decision not widely shared in post-war theatre. In fact, as Arjomand reveals in the book's final section, after the war, collaborators with the Nazi regime were frequently cast to play Jewish victims. The most notorious case of this is perhaps Paul Hörbiger, scion of an Austrian theatre dynasty, who performed in Rolf Schneider's documentary play Trial in Nuremberg as Abraham Sutzkever, a survivor who had actually testified in Nuremberg. Arjomand goes on to relate a story that almost defies belief: after a performance of Trial in Nuremberg, the Burgtheater in Vienna hosted a soirée where Sutzkever sat between the playwright Schneider and the actor who had recited his testimony on stage Paul Hörbiger. Given Hörbiger's erstwhile uneasy complicity with the Nazi regime, he stayed, perhaps unsurprisingly, silent throughout dinner.

The book's conclusion moves beyond the historical frame of the prior sections. In a sweeping survey of recent theatre productions, Arjomand once again foregrounds what seems to be the crux of the book: 'At the theatre, the public is constituted both by the action on stage and by the people sitting next to each other in the dark, wondering what everyone else thinks. Theater at its best does not offer justice according to law, or morality according to rules, but a space where people judge in company of others' (p. 179).

This is a highly original book that confidently speaks to different audiences: both political theorists and students of performance studies will have much to learn from it. Arjomand manages to crosspollinate findings between these two disciplines such that surprising insights emerge. The book's outstanding quality can perhaps be gauged through a metaphor that Arjomand borrows from Arendt to explain her historiographical method: 'pearl fishing'. There are many pearls to be found in this book - from fine-grained reconstructions of specific plays to grand claims about the critical potential of theatre. These, by themselves, make the book a worthwhile and rewarding read.

But the metaphor of pearl fishing also highlights a weakness in this book: its tendency to express illuminating ideas in isolation from one another. Some of the 
thoughts outlined in the introduction are never fully explored later on. For example, the suggestion that the Holocaust prompted artists and theorists to reorient their aesthetics by turning to German Enlightenment philosophers such as Schiller or Lessing is intriguing but never comprehensively explained. Equally problematic appears to be a general lack of transparent structure: the book's later sections sometimes seem quite detached from the chapters on Arendt, Brecht and Piscator. In sum, the pearls that Arjomand has provided for her readers are a delight, but the book would perhaps have been even better had those been strung up to form a coherent whole. These qualms notwithstanding, I can recommend this book to all those interested in the politics and aesthetics of judgment.

Publisher's Note Springer Nature remains neutral with regard to jurisdictional claims in published maps and institutional affiliations.

Mathias Thaler University of Edinburgh, Edinburgh EH8 9YL, Scotland, UK mathias.thaler@ed.ac.uk 